\title{
The Impact of Producer Services Agglomeration on Scientific and Technological Innovation from the Perspective of Global Value Chain Danlei Yang1,*
}

\author{
'School of Economics and Management, Beijing JiaoTong University, Beijing 100044, China \\ *Corresponding author. Email: 18120552@bjtu.edu.cn
}

\section{Keywords: scientific and technological innovation, producer services agglomerate, Global Value Chain, manufacturing industry}

\begin{abstract}
This paper theoretically analyses the mechanism of the agglomeration of producer services on technological innovation of manufacturing industry, and the effect of participation in Global Value Chain (Hereinafter referred to as GVC) on the relationship among them, and then empirical tests are carried out with industry panel data from 2003 to 2014, using interactive regression model and comprehensive FGLS estimation method. It is found that the agglomeration of producer services can promote the technological innovation of manufacturing industry, and the participation in GVC can enhance this relationship through three ways: strengthening the connection in inter-industry, obtaining more technology spill-over, and further reducing costs. In addition, increasing investment in $\mathrm{R} \& \mathrm{D}$ funds and personnel, introducing foreign investment cautiously and attaching importance to independent R\&D activities will also help to promote scientific technological innovation level of manufacturing industry.
\end{abstract}

\section{INTRODUCTION}

Since the reform and opening-up, China's manufacturing industry has developed rapidly relying on demographic dividend and factor price advantages, but its international competitiveness is weak. Under the background of the new normal, China's industry must rely on innovation to drive development. With the transformation of global economy from "industrial economy" to "service economy", producer services provide a way for the transformation and upgrading of manufacturing industry [1]. In recent years, China's producer service industry has developed rapidly, and has the characteristics of agglomeration [2].

With the deepening of global division of production, the participation of Chinese manufacturing industry in GVC is increasing. Producer services can link and coordinate all stages in the value chain; it can also participate in international production as a stage such as R\&D or sales [3], in order to improve the operation efficiency and value-added content of manufacturing industry. Participation in GVC makes the relationship between producer services and manufacturing industry closer.

The purpose of this paper is to explore how the agglomeration of producer services can improve the technological innovation level of manufacturing industry, and how the participation in GVC affects their relationship.

\subsection{Related Work}

The existing literature shows that producer services play a positive role in manufacturing innovation. The agglomeration of producer services is the main way to inject human capital and knowledge capital into manufacturing industry [1]. Specialized agglomeration can promote innovation by sharing innovation resources, increasing competition pressure and technology spillovers [4]; diversified agglomeration can reduce the production and search costs of industrial enterprises, in order to improve the innovation ability [5].

The existing literature also shows that participating in manufacturing GVC can promote innovation level mainly through "technology spill-over effect" and "learning effect" [6], especially 
developing country enterprises can obtain knowledge and improve learning and innovation ability by participating in GVC [7].

\subsection{Contribution}

Different from the existing literature, this paper innovatively studies the relationship between the agglomeration of producer services and the technological innovation of manufacturing industry under the framework of GVC. With the deepening of product division, the influence of participation in GVC on the industries of various countries cannot be ignored. This study can clarify the role of producer services in innovation from the perspective of GVC.

\section{Theoretical Analysis and Research Hypothesis}

The agglomeration of producer service industry can influence the technological innovation of manufacturing industry mainly through three ways: (1) Producer service industry has the characteristics of strong industrial relevance and high concentration of knowledge capital. Producer service industry can provide high-quality human capital and technology for manufacturing enterprises through agglomeration. (2) The specialization agglomeration of producer services can help to form economies of scale, and strengthen intra-industry competition, which will help to improve the innovation level of producer services enterprises. When connecting with manufacturing enterprises, higher innovation level will help inter-industry technology spill-over. (3) In the case of diversified agglomeration of producer services, manufacturing enterprises can find different types of producer services in the same region to save search costs; outsource multiple service stages to save production costs, so that more funds can be used for innovation.

Hypothesis 1: the agglomeration of producer services is helpful to promote the technological innovation of manufacturing industry.

Participating in GVC can enhance the promotion of manufacturing service industry agglomeration on technological innovation in manufacturing by following ways.

First, strengthen-inter industry relations. Under the GVC mode, the whole production process is divided into independent production stages scattered around the world, which need the connection and coordination of producer services such as transportation and communication technology. The producer services run through all production stages and are more closely linked with the manufacturing industry, which can better inject human capital and knowledge into the manufacturing enterprises.

Second, absorb more technology spill-overs. On the one hand, by participation in GVC, domestic enterprises must "learn from export" to meet the high standard requirements of upstream foreign enterprises for export products, which can improve their learning and absorption capacity, and helps to absorb technology spill-overs from the agglomeration of producer services. On the other hand, domestic enterprises have opportunities to obtain technology spill-overs from enterprises in developed countries.

Third, further reduce costs. In order to gain a comparative advantage in the key production stage, the enterprises participating in GVC will import advanced production equipment from abroad to reduce costs, and will also outsource more services to carry out specialized production in the key production stage. The money saved through cost reduction can be used for innovation activities to achieve technological breakthroughs in key production stages.

Hypothesis 2: participation in GVC can strengthen the promotion of productive service industry agglomeration to manufacturing science and technology innovation.

\section{Empirical Research}

\subsection{Variables}

Explained variable is the level of scientific and technological innovation (patent), measured by the number of effective invention patents. 
The main explanatory variables include: producer services agglomeration (service). Five industries as producer services are selected with reference to Liu et al. [8]. Using the $\theta_{i}$ index defined by Li et al. [9] to measure the agglomeration degree of producer services, as shown in equation (1).

$$
\theta_{i}=\frac{\sum_{j}^{m} \sqrt{\left(X_{i j}-X_{i}\right)^{2}}}{2 \sum_{j=1}^{m} X_{i j}}+\frac{m-k}{m}
$$

GVC participation $(g v c)$. Using the GVC forward participation index defined by Wang et al. [10] to measure it, as shown in equation (2).

$$
\mathrm{GVCPt}_{-} f^{s}=\frac{V_{-} G V C^{s}}{\widehat{\nabla}^{s} X^{s}}=\frac{V_{-} G V C_{-} R^{S}}{\widehat{\nabla}^{s} X^{s}}+\frac{V_{\_} G V C_{-} D^{s}}{\widehat{V}^{s} X^{s}}+\frac{V_{-} G V C_{-} F^{S}}{\widehat{V}^{s} X^{s}}
$$

The control variables include: (1) R\&D expenditure $(r d)$, measured by R\&D funds; (2) R\&D personnel (person),measured by full-time equivalence of R\&D personnel; (3property rights (state), calculated as the method of Wang et al. [6]; (4)foreign direct investment ( $f d i)$, calculated as the method of Qi et al. [11]; (5)other technological activities (other), measured by the sum of funds used by enterprises for technology introduction, technological transformation and digestion.

\subsection{Model Setting}

Firstly, the level of technological innovation in manufacturing industry is taken as the explanatory variable, and the agglomeration degree of producer services industry is taken as the core explanatory variable, and a benchmark model is constructed, as shown in equation (3).

$$
\text { patent }_{i t}=\beta_{0}+\beta_{1} \text { service }_{i t}+\beta_{2} \text { rd }_{i t}+\beta_{3} \text { person }_{i t}+\beta_{4} \text { state }_{i t}+\beta_{5} \text { fdi }_{i t}+\beta_{6} \text { other }_{i t}+\varepsilon_{i t}(3)
$$

In equation (3), $i$ represents industry, $t$ represents time; $\varepsilon_{i t}$ is the error term; $\beta_{0}$ is a constant; $\beta_{1}$ $\beta_{6}$ are the coefficients corresponding to the variables; the meaning of the variables is as described above.

In order to further explore the influence mechanism after taking participation in GVC into consideration, the interaction term and GVC participation variable are added into the benchmark model, which is expanded to equation (4).

$$
\begin{array}{r}
\text { patent }_{i t}=\beta_{0}+\beta_{1} \text { service }_{i t}+\beta^{\prime} \text { gvc }_{i t}+ \\
\beta^{\prime \prime} \text { service }_{i t} \cdot g v c_{i t}+\beta_{2} \text { rd }_{i t}+\beta_{3} \text { person }_{i t}+ \\
\beta_{4} \text { state }_{i t}+\beta_{5} \text { fdi }_{i t}+\beta_{6} \text { other }_{i t}+\varepsilon_{i t}
\end{array}
$$

In equation (4), service $_{i t} \cdot g v c_{i t}$ is the interaction term.

\subsection{Data}

By matching industry classification standards of different databases, this paper selects the panel data of 17 sub sectors of China's manufacturing industry from 2003 to 2014 as samples. The data of the number of employees in producer services comes from "China Statistical Yearbook"; the data of GVC forward participation index come from WIOD database and UIBE database; the data used to calculate property rights and foreign direct investment are from "China Industrial Statistics Yearbook"; other data are from "China Science and Technology Statistical Yearbook".

\section{Results and Aanalysis}

\subsection{Basic Regression Results}

First, Wald test, Wooldridge test and Pesaran test are carried out, and the results are significant. Therefore, comprehensive FGLS is used for parameter estimation. In order to avoid the error of the result caused by the endogeneity problem, the core explanatory variables are delayed for one period; in order to avoid the multicollinearity problem caused by the addition of interaction terms, all variables are centralized. The basic estimation results are shown in Table 1. 
Table 1 Basic estimation results

\begin{tabular}{|c|c|c|}
\hline Variables & $\begin{array}{c}\text { (1) } \\
\text { Comprehensive FGLS }\end{array}$ & $\begin{array}{c}(2) \\
\text { Comprehensive FGLS }\end{array}$ \\
\hline service & $\begin{array}{c}2.6527 * * * \\
(0.4497)\end{array}$ & $\begin{array}{c}2.3168 * * * \\
(0.6606)\end{array}$ \\
\hline gvc & & $\begin{array}{c}2.7922 * * * \\
(0.9242)\end{array}$ \\
\hline service*gvc & - & $\begin{array}{c}16.6696^{* * * *} \\
(4.8790)\end{array}$ \\
\hline rd & $\begin{array}{c}1.2202 * * * \\
(0.0752)\end{array}$ & $\begin{array}{c}1.2755 * * * \\
(0.0578)\end{array}$ \\
\hline person & $\begin{array}{c}0.8427 * * * \\
(.0512)\end{array}$ & $\begin{array}{c}0.7832 * * * \\
(0.0483)\end{array}$ \\
\hline state & $\begin{array}{l}0.3230 \\
(.3665) \\
\end{array}$ & $\begin{array}{c}0.4769 \\
(0.4575) \\
\end{array}$ \\
\hline fdi & $\begin{array}{c}-1.6725 * * * \\
(0.2008)\end{array}$ & $\begin{array}{c}-1.6543 * * * \\
(0.2972)\end{array}$ \\
\hline other & $\begin{array}{c}.0075 \\
(.0089)\end{array}$ & $\begin{array}{c}0.0106 \\
(0.0074)\end{array}$ \\
\hline _cons & $\begin{array}{c}283.1776 * * * \\
(38.7021) \\
\end{array}$ & $\begin{array}{c}257.6465 * * * \\
(49.2608) \\
\end{array}$ \\
\hline Industry fixed & Yes & Yes \\
\hline Year fixed & Yes & Yes \\
\hline Wald chi2(16) & $3354.10 * * *$ & $8558.68 * * *$ \\
\hline Wald test & 0.0000 & 0.0000 \\
\hline Wooldridge Test & 0.0073 & 0.0068 \\
\hline Pesaran Test & $3.7060 * * *$ & $1.7380 *$ \\
\hline $\mathrm{N}$ & 187 & 187 \\
\hline
\end{tabular}

Note: (1) $* * *$ and $* * *$ are significant at $10 \%, 5 \%$ and $1 \%$, respectively; (2) the values in parentheses are corresponding standard errors.

The result (1) in Table 1 shows that the coefficient of producer services agglomeration is significantly positive, which verifies the hypothesis 1 that producer services agglomeration helps to improve the level of technological innovation of manufacturing industry. From the result (2) in Table 1, it can be seen that the coefficient of producer services agglomeration is still significantly positive, and the coefficient of interaction term is also significantly positive, which verifies hypothesis 2 , indicating that participation in GVC can enhance the promotion of producer services agglomeration on manufacturing science and technology innovation.

In terms of control variables, both in the benchmark model and the extended model, the coefficients of $R \& D$ expenditure and $R \& D$ personnel are significantly positive; the coefficient of foreign direct investment is significantly negative, while the coefficient of property right and other technical activities is not significant.

\subsection{Robustness Test}

In order to further verify the robustness of the research results, two methods are used to re estimate the extended model (equation (4)), and the results are shown in Table 2.

Table 2 Robustness test results

\begin{tabular}{|c|c|c|}
\hline Variables & $\begin{array}{c}\text { (1) } \\
\text { Comprehensive FGLS }\end{array}$ & $\begin{array}{c}\text { (2) } \\
\text { Comprehensive FGLS }\end{array}$ \\
\hline service & $\begin{array}{l}0.4299 * * * \\
(0.1556)\end{array}$ & $\begin{array}{c}4.3642 * * * \\
(0.7392)\end{array}$ \\
\hline gvc & $\begin{array}{c}1.0301 * * * \\
(0.1850)\end{array}$ & $\begin{array}{l}1.8778 * * \\
(0.9443)\end{array}$ \\
\hline service*gvc & $4.5842 *$ & $22.8966 * * *$ \\
\hline
\end{tabular}




\begin{tabular}{|c|c|c|}
\hline & $(2.3735)$ & $(5.1010)$ \\
\hline crisis & & $\begin{array}{c}0.3530 * * * \\
(0.0658)\end{array}$ \\
\hline \multirow{2}{*}{ cons } & $90.0538 * * *$ & $215.0867 * * *$ \\
& $(10.3513)$ & $(55.4728)$ \\
\hline Industry fixed & Yes & Yes \\
\hline Year fixed & Yes & $215.0867 * * *$ \\
\hline Wald chi2(16) & $58612.97 * * *$ & 187 \\
\hline $\mathrm{N}$ & 187 & \\
\hline
\end{tabular}

Note: (1) $* * *$ and $* * *$ are significant at $10 \%, 5 \%$ and $1 \%$, respectively; (2) the values in parentheses are corresponding standard errors; (3)due to the limitation of the length of the paper, the estimation results of the control variables are omitted.

First, the explained variable is replaced by the number of invention patents. According to the results (1) in Table 2, although the significance of interaction terms has decreased, the coefficients of core explanatory variables have not changed and are still significant.

Second, considering the issue of economic shocks. Economic shocks may cause model setting errors, so the impact of the 2008 financial crisis cannot be ignored. Adding the financial crisis virtual variable (crisis). When the year is less than 2008, crisis is 0, otherwise, it is 1 . The estimation results in Table 2 (2) shows that the estimation result of this paper is robust.

\section{Conclusion}

Based on the panel data of China's industry from 2003 to 2014, this paper theoretically analyzes the impact of producer services agglomeration on the technological innovation of manufacturing industry, and further analyzes the impact of participation in GVC on the relationship between them, and finally verifies the impact of participation in GVC on the relationship between Producer Services Agglomeration and technological innovation through interaction regression.

It is found that the agglomeration of producer services can promote the level of technological innovation of manufacturing industry through the effects of industrial association, knowledge spillover and cost reduction. Participation in GVC can strengthen these three effects, in order to enhance the promotion of the agglomeration of producer services on the technological innovation of manufacturing industry.

It is necessary to maintain the development of producer service industry and speed up the formation of agglomeration area. Local enterprises should actively participate in GVC, actively absorb technology spill-overs of advanced foreign enterprises. In addition, increasing investment in R\&D funds and personnel, introducing foreign investment cautiously and attaching importance to independent R\&D activities will also help to promote scientific technological innovation level of manufacturing industry.

\section{References}

[1] Y. Yuan, R. Guo, Productive Service Industry Agglomeration, Manufacturing Industry Agglomeration and Technological Innovation-An Empirical Study Based on Provincial Panel Data. Economist, (5) (2018) 23-31. DOI: https://doi.org/10.16158/j.cnki.51-1312/f.2018.05.005

[2] S. He, F. Chen, Productive Service Industry Agglomeration and Technological Innovation-Theory and Empirical Analysis, Reform of Economic System, (5) (2017) 188-194.

[3] P. Low, The Role of Services in Global Value Chains, Real Sector Working Paper,2013.

[4] Y. Ji, Q. Yang, Agglomeration of Producer Services and Innovation-Driven Development, Forum on Science and Technology in China, (4)(2017) 69-75, 102. DOI: https://doi.org/10.13580/j.cnki.fstc.2017.04.010

[5] M. Liu, P. Li, N. Xu, Does Producer Services Promote the Improvement of Technological 
Innovation Efficiency? -Based on Perspective of Different Agglomeration, Resource Development \& Market, 34(12) (2018) 1717-1725, 1737.

[6] Y. Wang, H. Lin, C. Lv, The Effect of Global Value Chain Embeddedness on Technical ProgressAn Empirical Study on Panel Data of China's Industries, China Industrial Economics, (9) (2014) 65-77. DOI:https://doi.org/10.19581/j.cnki.ciejournal.2014.09.005

[7] C. Pietrobelli, R. Rabelloti, Global Value Chain Meet Innovation Systems: Are There Learning Opportunities for Developing Countries, World Development, 39(7) (2011) 1261-1269. DOI: https://doi.org/10.1016/j.worlddev.2010.05.013

[8] Y. Liu, J. Xia, Y. Li, Producer Services Agglomeration and Manufacturing Upgrading, China Industrial Economics, (7) (2017) 24-42. DOI: https://doi.org/10.19581/j.cnki.ciejournal.2017.07.002

[9] T. Li, F. Zhong, H. Gu, Simple Measures of Industrial Agglomeration and its Comparison, Statistical Research, (11) (2007) 64-68. DOI: https://doi.org/10.19343/j.cnki.111302/c.2007.11.012

[10] Z. Wang, S. Wei, X. Yu and K. Zhu, Measures of Participation in Global Value Chains and Global Business Cycles, NBER Working Paper 23222, 2017b. DOI:https: //doi.org/10.3386/w23222

[11] J. Qi, H. Xu, Industry Heterogeneity, Appropriate Intellectual Property Protection and Technology Progress of Export-Analysis Based on the Panel Data of Chinese Industries, China Industrial Economics, (2) (2012) 79-88. DOI: https://doi.org/10.19581/j.cnki.ciejournal.2012.02.008 